\title{
INTERSPECIFIC DIFFERENCES BETWEEN ATLANTIC SALMON AND ARCTIC CHARR IN SUSCEPTIBILITY TO INFECTION WITH LARVAL AND ADULT CALIGUS ELONGATUS: EFFECT OF SKIN MUCUS PROTEIN PROFILES AND EPIDERMAL HISTOLOGICAL DIFFERENCES
}

\author{
Ahmed MUSTAFA ${ }^{1 *}$, Barbara M. MACKINNON ${ }^{2}$, Wojciech PIASECKI ${ }^{3}$ \\ ${ }^{1}$ Department of Biology, Indiana University-Purdue University, Fort Wayne, IN 46805, USA \\ ${ }^{2}$ Huntsman Marine Science Centre, St. Andrews, NB, Canada \\ ${ }^{3}$ Division of Fish Diseases, Agricultural University of Szczecin, Poland
}

\begin{abstract}
Mustafa A., MacKinnon B.M., Piasecki W., 2005. Interspecific differences between Atlantic salmon and Arctic charr in susceptibility to infection with larval and adult Caligus elongatus: effect of skin mucus protein profiles and epidermal histological differences. Acta Ichthyol. Piscat. 35 (1): 7-13.
\end{abstract}

Background. Arctic charr, Salvelinus alpinus (L.), are known to harbour significantly more sea lice, Caligus elongatus von Nordmann, 1832, than do Atlantic salmon, Salmo salar L. This research investigated whether this is due to differences in initial infection or to resettlement/loss of mobile adults. Skin mucus protein profiles and epidermal histology were also studied as two characteristics that might help explain interspecific differences in host susceptibility. Materials and methods. Atlantic salmon and Arctic charr were sampled from the sea-pen after 12 weeks of exposure to natural infection. Fishes were examined for sea lice counts and mucus was analysed for protein profiles using standard methods of poly-acrylamide gel electrophoresis. Epidermal tissue of fishes around chalimus attachment sites was also examined by transmission electron microscopy.

Results. Interspecific differences in host susceptibility were determined not to be due to differences in initial infection rate, as charr and salmon had similar numbers of attached chalimi. Adult parasites were significantly more numerous on charr as a result of resettlement of adults lost by other fishes in the area. Gel electrophoresis indicated that salmon had a greater abundance of skin mucus proteins than charr, particularly in the 30-42 and 67-94 kDa range. Ultrastructural analysis of epidermal tissue indicated that charr had more mucous cells and showed evidence of possible osmotic stress. Interspecific differences also existed in intercellular adhesion characteristics. Salmon and charr showed a similar absence of inflammation around chalimus attachment sites.

Conclusions. Artic charr had a more intense infection with Caligus elongatus than did salmon corresponding to fewer potentially antagonistic proteins in the mucus. Perhaps also, the epidermis of charr provides more easily accessible food for the sea lice. Higher levels of stress in charr in sea water may also have predisposed them to higher sea lice infections.

Keywords: Atlantic salmon, Salmo salar, Arctic charr, Salvelinus alpinus, epidermal histology, sea lice, susceptibility

\section{INTRODUCTION}

Intensity of infection with a given parasite can vary greatly between individual hosts and host species. Underlying factors that determine whether a fish or group of fish resists a parasite are complex and may be based on morphological, physiological, behavioural, immunological, or nutritional characteristics. Cultured salmonids, in the northern hemisphere are plagued by two major species of sea lice Lepeophtheirus salmonis (Krøyer, 1837) and Caligus elongatus von Nordmann, 1832. C. elongatus is more prevalent along the Atlantic coast of Canada (Hogans and Trudeau 1989, Piasecki and MacKinnon 1995) and is known to infect over 80 different fish species
(Kabata 1979). Intensity of infection with C. elongatus, varies considerably even among fish with the same genetic background residing in the same sea-pen (Mustafa and MacKinnon 1997), however and in addition different species of hosts have shown a wide range in susceptibility to sea lice (Johnson and Albright 1992, Nagasawa et al. 1993). For example, Arctic charr, Salvelinus alpinus (L.), were shown to be significantly more heavily infected with C. elongatus than Atlantic salmon, Salmo salar L., (cf. Mustafa and MacKinnon 1999).

This study had two objectives. The first was to determine if the infection differences in Atlantic salmon and Arctic charr were due to initial attraction and attachment of

\footnotetext{
* Correspondence: Dr. Ahmed Mustafa, Department of Biology, Indiana University-Purdue University, Fort Wayene, IN 46805, USA, phone: (+1-260) 481 6328, fax: (+1-260) 481-6087, e-mail: mustafaa@ipfw.edu
} 
larval sea lice or to loss or resettlement of adult sea lice, as adult $C$. elongatus are known to leave their host for brief swimming activity (Neilson et al. 1987). The second objective was to investigate host factors that may affect differences in infection intensity between Atlantic salmon and Arctic charr. While differences in infection intensity with $C$. elongatus between Atlantic salmon and Arctic charr may be due to the effects of stress, to innate differences in fish behaviour or skin characteristics or a combination of these and other factors, the skin was chosen as the obvious tissue for comparison since the parasite feeds on the skin mucus and epidermal cells (Kabata 1974, MacKenzie and Morrison 1989). Lesion associated with the C. elongatus frontal filament attachment were depicted on a SEM micrograph by Piasecki and MacKinnon (1993).

\section{MATERIALS AND METHODS}

Fish source and maintenance

Two-year-old Atlantic salmon smolts and two-year-old Arctic charr each weighing between 200 and $400 \mathrm{~g}$, were obtained from the Huntsman Marine Science Centre, St. Andrews, NB, and divided into two groups of least 100 fish per group. Fishes were kept in fresh water for 14 weeks and then gradually acclimated to sea water over a two-week period. Fishes were then transferred to and kept in a sea-pen for 12 weeks and allowed to naturally acquire sea lice infections. Experimental fishes were used to investigate infection intensity, mucous protein profiles, and histology of epidermal tissue.

Comparison of larval and adult C. elongatus infections

Experimental fishes were collected by a dip-net from the sea-pen after 12 weeks exposure to infection and individually placed in plastic bags before being killed by a blow to the head and kept frozen for further analysis. For examination, fishes were thawed and the total numbers of larval and adult sea lice on the fish were counted. Prevalence, abundance, and mean intensity were calculated following the definitions of Bush et al. (1997).

\section{Mucous protein profiles}

Ten uninfected Atlantic salmon and ten uninfected Arctic charr, maintained for two weeks in sea water in laboratory tanks were dip-netted and hand-held while mucus samples were collected by gently running a glass slide along a 2-cm length of skin. These samples were held on ice and analysed within $24 \mathrm{~h}$ for protein profiles using standard methods of poly-acrylamide gel electrophoresis (SDS-PAGE) (Laemmli 1970).

\section{Histology of epidermal tissue}

Salmon and charr held in sea-pens and exposed to sea lice for 12 weeks were dip-netted and than killed by a blow to the head. Epidermal tissue around chalimus attachment sites were excised from 10 fish of each species. Uninfected tissue samples were obtained from 10 fish of each species kept in sea-water laboratory tanks. Samples were prepared for transmission electron microscopy using Karnovsky's fixture ( $\mathrm{pH} 7.2$ ) for $24 \mathrm{~h}$, washing $24 \mathrm{~h}$ in sodium cacodylate buffer, and post-fixing in $1 \%$ osmium tetroxide. Following post-fixation, samples were dehydrated in acetone and embedded in Epon Araldite resin. Semithin sections, $(1.0 \mu \mathrm{m})$ and ultrathin sections $(60-70 \mathrm{~nm})$ were cut using an LKB ultramicrotome and glass knives. Semithin sections were stained with toluidine blue and examined under a light microscope, and ultrathin sections were stained with uranyl acetate and lead citrate and examined using a Phillips 400T transmission electron microscope.

Statistical analysis

Data were analysed statistically using the Student's t-test (significance when $P<0.05$ ). Values reporter herein are means \pm standard error of the mean $\left(s_{\bar{x}}\right)$.

\section{RESULTS}

There was no significant difference in the mean numbers of attached larvae between the two hosts species. However, Arctic charr had significantly more $(P<0.05)$ adult sea lice than had Atlantic salmon (Fig. 1). Skin

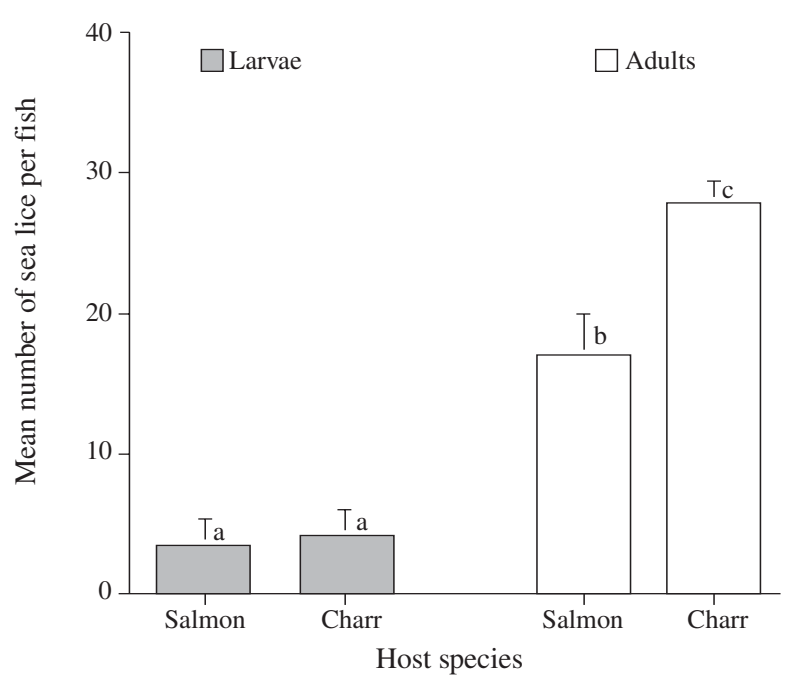

Fig. 1. Mean $\left( \pm s_{\bar{x}}\right)$ numbers of C. elongatus larvae (shaded) and adults (blank) per fish on Atlantic salmon and Arctic charr; means with different letters are significantly different

mucus protein profiles for Atlantic salmon showed more protein bands than did samples from charr in the 67-94 $\mathrm{kDa}$ range. Salmon also had an additional strongly staining band between 30 and $42 \mathrm{kDa}$ (Fig. 2).

Light and electron micrographs of uninfected salmon epidermis indicated typically intact layer of outer squamous epithelial cells (Fig. 3A) bearing micro ridges (Fig. 3B). Distal Malpighian cells were interspersed with mucous cells. More proximal Malpighian cells were characterized by large nuclei and a cytoplasm having few vacuoles and limited endoplasmic reticulum. Several intercellular junctions and areas of interdigitation between Malpighian cells were present (Fig. 3C). An extensive abrasion of the epidermis was evident (Fig. 4) on electron micrographs showing epidermis of chalimi-infected salmon. Epidermal cells were 


\section{$\begin{array}{llllllll}S & S & S & S & M & C & C & C\end{array}$ $s \mathrm{~m} m \mathrm{~m} \mathbf{m} \mathrm{m}$}
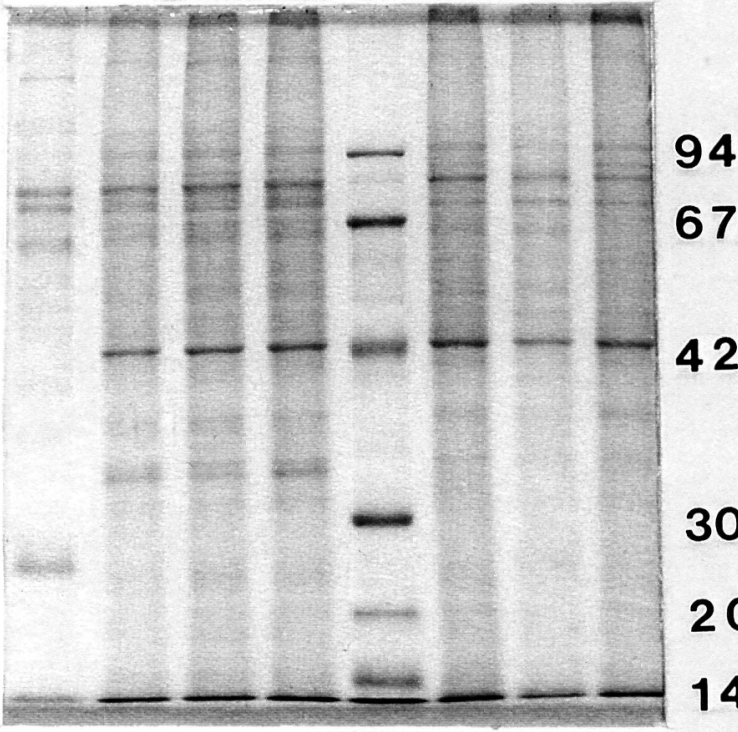

Fig. 2. SDS-PAGE gel (representative photograph) of skin mucus samples and serum from Atlantic salmon (S) and skin mucus samples from Arctic charr (C) (each lane represents one fish sample); s, serum; m, mucus; MW, molecular weight standards (scaled in $\mathrm{kDa}$ )

absent down to the basement membrane. These eroded areas were surrounded by ripped and dying cells (Fig. 4A). Cells with pycnotic nuclei were present next to the parasitemade abrasions and normal epithelial cells bearing micro ridges were absent (Fig. 4B). Normal Malpighian cells were located near the damaged area and there was no evidence of white blood cell infiltration, excessive mucous cells or melanocytes.

Light and electron micrographs of uninfected charr epidermis indicated an intact layer of squamous cells (Fig. 5A) with micro ridges (Fig. 5B). Mucous cells were numerous and were seen discharging mucus towards the external surface. Malpighian cells were irregular in outline and contained large electron-dense nuclei (Fig. 5C). They also contained many electron-lucent inclusion bodies similar to the mucopolysaccharide inclusions evident in mucous cells. Some specimens showed extensive vesicle-like areas in the Malpighian cells. Few intercellular junctions were evident between Malpighian cells but the outer cell membrane appeared elaborately folded, interdigitating with adjacent cells (Fig. 5C inset). There was some evidence of loss of cell contact in more distal areas since gaps were evident between some cells. The epidermis of charr in areas were chalimi were attached (Fig. 6) showed erosions reaching down to the basement membrane (Fig. 6A). Cells with pycnotic nuclei, at the edges of the eroded areas, were evident but not as obvious as those in salmon. Epidermal tissue adjacent to the immediate area of attachment appeared similar to that of uninfected fish. There was no evidence of infiltration of white blood cells, melanocytes, or hyperplastic tissue.

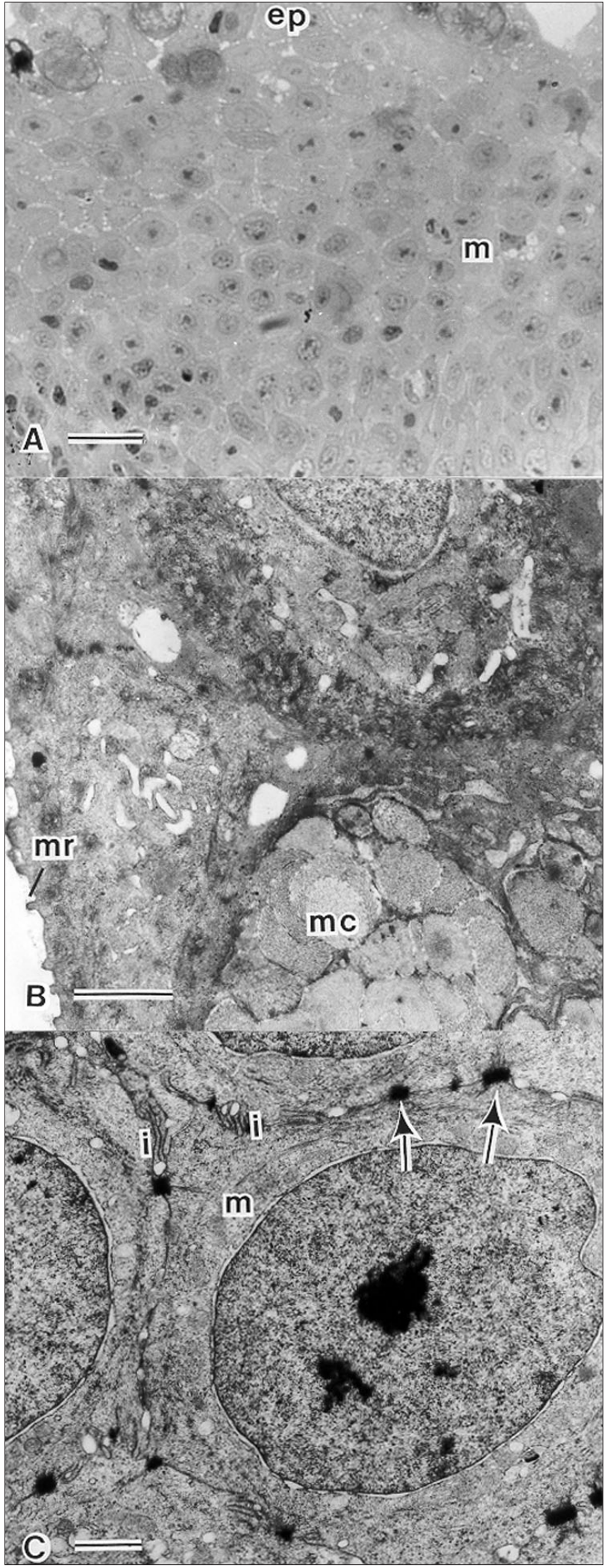

Fig. 3. Light and electron micrographs of sections through epidermis of Atlantic salmon;. (A) light micrograph of a normal epidermis; Ep, intact outer epidermal layer; m, Malpighian cells; bar $=30 \mu \mathrm{m}$; $(\mathrm{B})$ electron micrograph of a normal epithelium; mr, micro ridges; mc, mucus-producing cells; bar $=10 \mu \mathrm{m} ;(\mathrm{C})$ electron micrograph of inner layers of normal epithelium; $\mathrm{m}$, Malpighian cells; I, intercellular junctions; bar $=1.0 \mu \mathrm{m}$ 


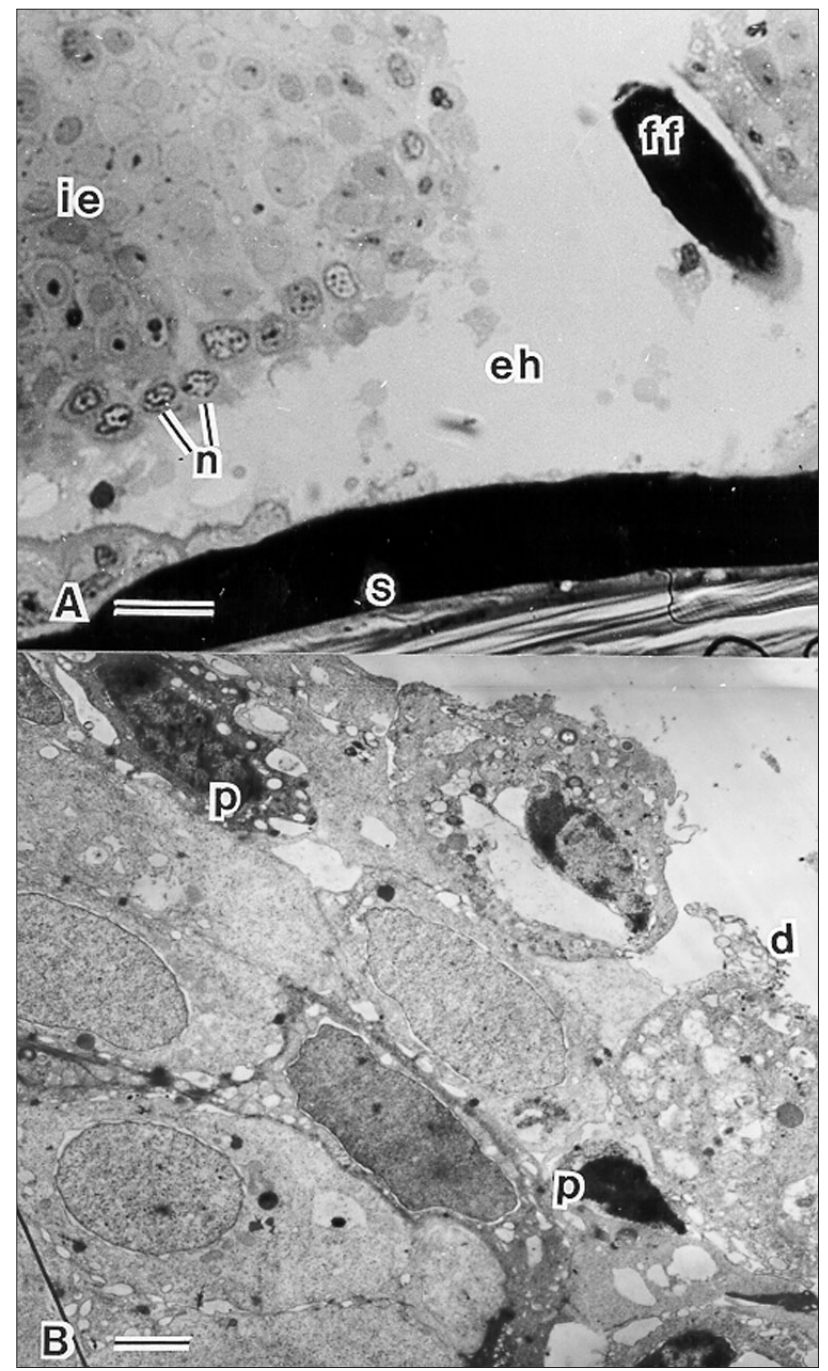

Fig. 4. Light and electron micrographs of sections through epidermis of Atlantic salmon infected with chalimus of Caligus elongatus; (A) light micrograph of damaged epidermis; ff, part of frontal filament; eh, eroded area; ie, intact epidermis; $\mathrm{n}$, necrotic cell; s, fish scale; bar $=30 \mu \mathrm{m}$; (B) electron micrograph of a damaged epithelium; $p$, pycnotic nucleus; $d$, blebbing of disrupted cell surface; bar $=2.0 \mu \mathrm{m}$

\section{DISCUSSION}

Some species of fish may be more susceptible to initial infection by the free-swimming copepodid larvae of Caligus elongatus, perhaps due to differences in swimming speed, location in the water column, chemical cues released into the water, or a more attractive micro-habitat detected by the lice upon initial attachment. The present study, however, did not show any differences in the intensity of attached $C$. elongatus larvae between Atlantic salmon and Arctic charr despite differences in the swimming behaviour of these two host species (Nortvedt and Holm 1988). It is known that infective sea lice larvae actively swim upward and are photosensitive (Johannessen 1978, Wootten et al. 1982, MacKinnon 1993b), and it is therefore reasonable to presume that they are in the upper water layer of a sea-pen during the day as they are attracted to light. According to Furevik et al.
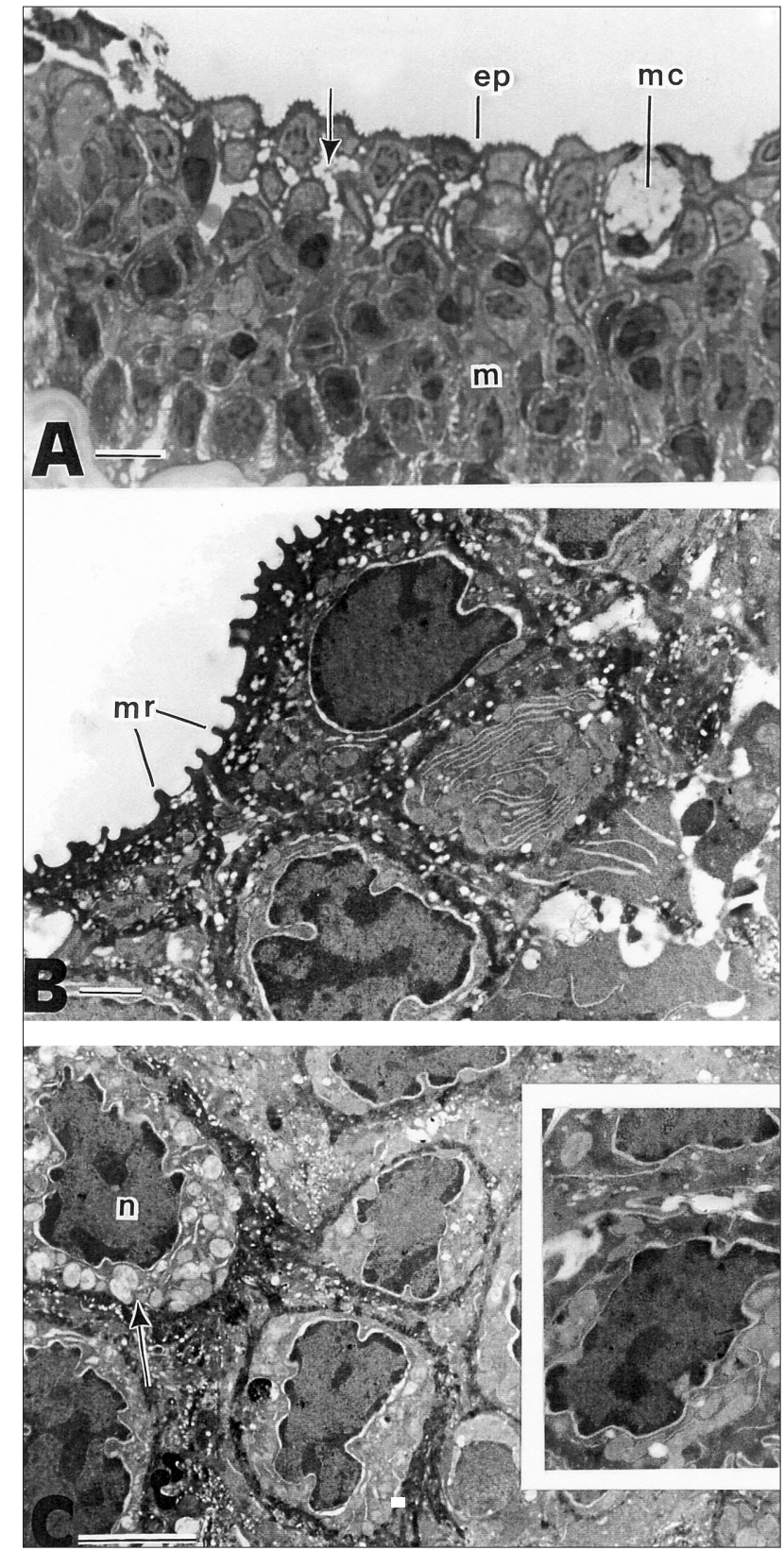

Fig. 5. Light and electron micrographs of sections through epidermis of Arctic charr; (A) light micrograph of a normal epidermis; ep, intact outer epidermis; mc, mucus-producing cells; m, Malpighian cells; $\uparrow$, space between cells (possible osmotic damage); bar $=30 \mu \mathrm{m}$; (B) electron micrograph of a normal epithelium; mr, micro ridges; bar $=1.0 \mu \mathrm{m}$; (C) electron micrograph of inner layers of normal epithelium; $\mathrm{n}$, nucleus of a Malpighian cell; arrow, cytoplasmic exclusion; bar $=1.0 \mu \mathrm{m}$; inset showing extensive intercellular digitation (arrow); bar $=1.0 \mu \mathrm{m}$

(1993), salmon are very active during the day and prefer to leap and roll at the surface. Holm (1988) and Nortvedt and Holm (1988) during their duoculture studies with salmon and charr also observed that salmon are dispersed, highly aggressive and maintain their position over charr within a sea-pen. Based on the relative position of the two species of fish within a sea-pen, it should follow that salmon would be more heavily infected than charr. 


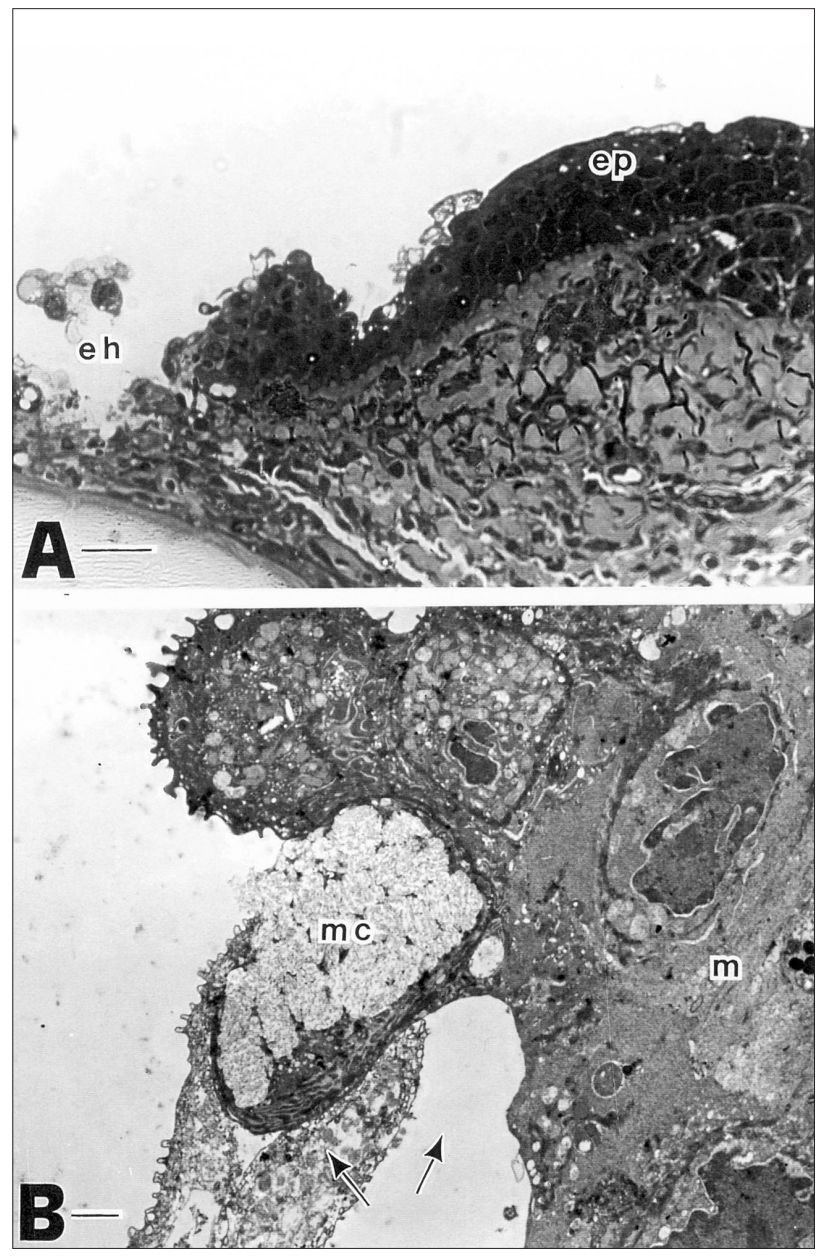

Fig. 6. Light and electron micrographs of sections through epidermis of Arctic charr infected with chalimi of Caligus elongatus; (A) light micrograph of a damaged epidermis; eh, eroded area; ep, epidermal cells; bar $=30 \mu \mathrm{m}$; (B) electron micrograph of a damaged epithelium; m, Malpighian cell; arrow, disrupted-an evidence of possible osmotic damage; bar $=1.0 \mu \mathrm{m}$

However, because salmon leap and are generally faster swimmers than charr (Nortvedt and Holm 1988), this could, in part, account for the "equalizing" in infection levels between the two host species since it theoretically seems more difficult for an infective larva of $C$. elongatus to attach to a rapidly-moving fish. On the other hand, charr were infected with significantly more of adult $C$. elongatus than were salmon. Presuming that these adults grew from larvae that infected charr and salmon equally, two explanations are possible to account for more adults on charr than salmon. The first explanation is that many of the larvae settling on salmon did not survive to adulthood. The second explanation is dependent on the knowledge that sea lice adults often swim away from their host and than back to the same or to different host. It is therefore possible that sea lice moved from salmon and onto charr. Charr are subdominant and less active than salmon (Adams et al. 1987, Linner et al. 1990) and thus they may be an easier target for adult louse reattachment. Thus, although salmon and charr are epipelagic in nature, the precise swimming depth of each species would influence the encounter rate with swimming adult sea lice (Nagasawa et al. 1993). Swimming speed, chemical cues, or other differences between charr and salmon, could also account for increased resettlement of sea lice on charr. The forgoing indicates that differences in infection intensity between salmon and charr are not due to differences in initial infection rate.

Differences in epidermal structure and function in Atlantic salmon and Arctic charr may be a factor contributing to the differences in adult sea louse infection intensity. Caligus elongatus larvae and adults feed on the mucus and epidermal cells of their hosts (Kabata 1974, MacKenzie and Morrison 1989). SDS-PAGE analysis of both Atlantic salmon and Arctic charr skin mucus identified extra protein bands in salmon mucus, the composition and function of which should be further investigated. These extra protein bands, may represent proteins that result in the death or departure of some of the mobile sea lice. Salmon and sea lice have co-evolved, and thus it might be expected that salmon have some protective proteins in their skin mucus. The molecular weight of these proteins are not consistent with the molecular weight of intact antibodies (MacKinnon 1991) and thus these proteins are not likely part of a specific immune response. Charr, on the other hand, have had less exposure to sea lice throughout their evolution as they make only brief forays into sea water (Johnson 1980).

In general, the ultrastructural appearance of the salmon epidermis in the present study agreed with the results of MacKinnon (1993a). The histology of epidermal tissues from uninfected and infected charr and salmon indicated that in both species, chalimus only caused small lesions as a result of feeding and attachment. There was little evidence of an inflammatory response and no increase in white blood cells in the area. In both infected and uninfected charr, there appeared to be gaps between the distal Malpighian cells that were not seen in salmon. Breakdown of intercellular connections is one of the first symptoms of infections associated with the skin (Ferguson 1989), and may also result from osmotic stress. This characteristic may be an indication that charr lost some epidermal integrity as a result of stress from being kept in sea water. Although charr thrive in intensive fresh water culture and some wild charr populations have a seaward migration each spring and a returning migration to fresh water each autumn, they thrive less well when kept for prolonged periods of time in sea water because of their low salinity tolerance and lower osmoregulation characteristics (Gjerdem 1975, Johnson 1980). This suggests that charr may be more stressed than salmon in estuarine sea-pens since, unlike salmon, charr do not undergo true smoltification (Delabbio 1995), and naturally do not remain in sea water as adults for a prolonged period of time.

Charr epithelial cells were interconnected by interdigitation of the cell membranes whereas salmon cells were connected by several intercellular junctions as well as by 
interdigitation of adjacent cell membranes. These findings may indicate that the charr epidermis is more easily disrupted by feeding sea lice thus providing a more easily utilized food source. Charr also appeared to have more epidermal mucus-producing cells than salmon. This observation was supported while handling the fish live; charr were more slimy than salmon. The abundance of mucus-producing cells in Arctic charr was described by Witkowski et al. (2004). Sea lice are believed to feed on host mucus and thus charr may provide more of this type of food than salmon. While few differences in the ultrastructure of infected sites were recorded between infected salmon and infected charr in this study, differences in histopathology have been recorded as a result of Lepeophtheirus salmonis infections on Atlantic-, Chinook- and coho salmon (Johnson and Albright 1992).

It is hypothesized from this study that charr have more intense infection with $C$. elongatus than do salmon as a result of fewer potentially antagonistic proteins in the mucus, and perhaps because the epidermis of charr provides more easily accessible food source for the sea lice. Mustafa and MacKinnon (1999) have suggested that higher stress levels in charr when in sea water may also predispose them to higher sea lice infections.

\section{ACKNOWLEDGEMENTS}

This study has been financed from research grants (to B.M.M.) from the Natural Sciences and Research Council (NSERC Canada), the Division of Fisheries and Oceans (DFO Canada), and the Atlantic Salmon Growers Association of New Brunswick, Canada.

\section{REFERENCES}

Adams N.J., Barton D.R., Cunjak R.A., Power G., Riley S.C., 1987. Diel patterns of activity and substrate preference in young Arctic char from the Koroc River, Northern Quebec. Canadian Journal of Zoology 66: 2500-2502.

Bush A.O., Lafferty K.D., Lotz J.M., Shostak A.W., 1997. Parasitology meets ecology on its own terms: Margolis et al. revisited. Journal of Parasitology 83: 575-583.

Delabbio J., 1995. Arctic charr culture in Atlantic Canada. pp. 83-106. In: Boghen E.D. (ed.) Cold-water aquaculture in Atlantic Canada. The Canadian Institute for Research on Original Development, Moncton, NB.

Ferguson H.W., 1989. Systematic pathology of fish. Iowa State University Press, Ames.

Furevik D.M., Bjordal Å., Huse I., Ferno A., 1993. Surface activity of Atlantic salmon (Salmo salar L.) in net pens. Aquaculture 110: 119-128.

Gjerdem T., 1975. Survival of Arctic charr in the sea during fall and winter. Aquaculture 6: 189-190.

Hogans W.E., Trudeau D.J., 1989. Caligus elongatus (Copepoda: Caligdae) from Atlantic salmon (Salmo salar) cultured in marine waters of the lower Bay of Fundy. Canadian Journal of Zoology 67: 1080-1082.

Holm J.C., 1989. Mono- and duoculture of juvenile Atlantic salmon (Salmo salar) and Arctic charr (Salvelinus alpinus).
Canadian Journal of Fisheries and Aquatic Sciences 46: $697-704$

Johannessen A., 1978. Early stages of Lepeophtheirus salmonis (Copepoda: Caligidae). Sarsia 63: 169-173.

Johnson L., 1980. The Arctic charr, Salvelinus alpinus. pp. 15-98. In: Balon E.K. (ed.) Charrs: salmonid fishes of the genus Salvelinus. Dr. W. Junk Publishers bv, The Hague.

Johnson S.C., Albright L.J., 1992. Comparative susceptibility and histopathology of the response of naive Atlantic, Chinook, and coho salmon to experimental infection with Lepeophtheirus salmonis (Copepoda: Caligidae). Diseases of Aquatic Organisms 14: 179-193.

Kabata Z., 1974. Mouth and mode of feeding of Caligidae (Copepoda), parasites of fishes, as determined by light and scanning electron microscopy. Journal of the Fisheries Research Board of Canada 31: 1583-1588.

Kabata Z., 1979. Parasitic Copepoda of British fishes. Ray Society, London.

Laemmli U.K., 1970. Cleavage of structural proteins during the assembly of the head of bacteriophage T4. Nature 227: $680-685$.

Linner J., Brannas E., Wiklund S.S., Lundqvist H., 1990. Diel and seasonal locomotor activity patterns in Arctic charr, Salvelinus alpinus (L.). Journal of Fish Biology 37: 675-685.

MacKenzie K., and Morrison J.A., 1989. An unusually heavy infestation of herring (Clupea harengus) L. with the parasitic copepod Caligus elongatus Nordmann, 1832. Bulletin of the European Association of Fish Pathologists 9:12-13.

MacKinnon B.M., 1991. Sea lice and Atlantic salmon: absence of immunoprotection in Salmo salar to Caligus elongatus. Bulletin of the Aquaculture Association of Canada 91 (3): 58-60.

MacKinnon B.M., 1993a. Host response of Atlantic salmon (Salmo salar) to infection by sea lice (Caligus elongatus). Canadian Journal Fisheries and Aquatic Sciences 50: 789-792.

MacKinnon B.M., 1993b. Response of the copepodid larvae of Caligus elongatus to light and the ultrastructure of the eyes. Canadian Journal Fisheries and Aquatic Sciences 50: 793-799.

Mustafa A., MacKinnon B.M., 1997. Interspecific variation in sea lice infection intensity between Atlantic salmon and Arctic charr. Bulletin of the Aquaculture Association of Canada 97 (2):30-32.

Mustafa A., MacKinnon B.M., 1999. Atlantic salmon, Salmo salar L., and Arctic char, Salvelinus alpinus (L.): comparative correlation between iodine-iodide supplementation, thyroid hormone levels, plasma cortisol levels, and infection intensity with the sea louse Caligus elongatus. Canadian Journal of Zoology 77: 1092-1101.

Nagasawa K., Ishida Y., Ogura M., Tadokoro K., Hiramatsu K., 1993. The abundance and distribution of Lepeophtheirus salmonis (Copepoda: Caligidae) on six species of Pacific salmon in offshore waters of the North Pacific Ocean and Bering Sea. pp. 166-178. In: Boxshall G.A., Defaye D. (eds.) Pathogens of wild and farmed fish: sea lice. Ellis Horwood, Chichester, UK.

Neilson J.D., Perry R.I., Scott J.S., Valerio O., 1987. Interactions of caligid ectoparasites and juvenile gadids on Georges Bank. Marine Ecology Progress Series 39: 221-232. 
Nortvedt R., Holm J.C.D., 1988. Behaviour and growth rate gain in Arctic charr (Salvelinus alpinus) and Atlantic salmon (Salmo salar) in mono- and duoculture when reared under two different densities. International Council for the Exploration of the Sea C.M./F: 26.

Piasecki W., MacKinnon B.M., 1993. Changes in structure of the frontal filament in sequential developmental stages of Caligus elongatus von Nordmann, 1832 (Crustacea, Copepoda, Siphonostomatoida). Canadian Journal of Zoology 71: 889-895.

Piasecki W., MacKinnon B.M., 1995. Life cycle of a sea louse, Caligus elongatus von Nordmann, 1832 (Copepoda, Siphonostomatoida, Caligidae). Canadian Journal of Zoology 73: 74-82.
Witkowski A., Kaleta K., Kuryszko J., Kusznierz J., 2004. Histological structure of the skin of Arctic charr, Salvelinus alpinus (L.) from Spitsbergen. Acta Ichthyologica et Piscatoria 34 (2): 241-251.

Wootten R., Smith J.W., Needham E.A., 1982. Aspects of the biology of the parasitic copepods Lepeophtheirus salmonis and Caligus elongatus on farmed salmonids, and their treatment. Proceedings of the Royal Society of Edinburgh B 81: 185-197.

Received: 5 April 2005 Accepted: 15 June 2005 